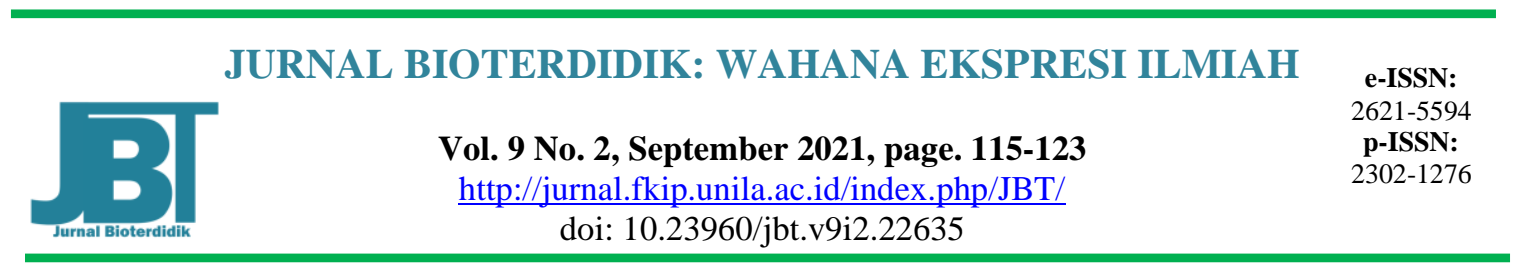

\title{
Korelasi Antara Keterampilan Generik Sains dengan Hasil Belajar Pada Konsep Ekologi
}

\author{
Fernida Siti Listiani* ${ }^{*}$ Endang Surahman, Romy Faisal Mustofa \\ Pendidikan Biologi, Fakultas Keguruan dan Ilmu Pendidikan, Universitas Siliwangi, Jl. Siliwangi No.24, \\ Kota Tasikmalaya 46115 Indonesia \\ *email : listiani.ei@gmail.com
}

Received: July 26, 2021

Accepted: September 25, 2021

Online Published: September 30, 2021

\begin{abstract}
The Correlation Between Generic Sciens Skills and Learning Outcomes Of Class Xi Ipa Students In Ecology Sub Materials. Generic science skills are important in the learning process because generic science skills is an internal factor that affect learning. This study aims to determine the relationship between generic science skills with student learning outcomes in ecology sub materials. The research method used is a correlation studySampling was done by purposive sampling of 2 classes namely XI MIPA 3 and XI MIPA 4 amount of 58 students. Data collect ion techniques were carried out with a post-test of 25 items in the form of descriptions to measure the ability generic science skills. The analysis data technique used Pearson product moment correlation regression test with $\alpha 0,05$. The result showed that there was a positive correlation between generic science skills and student learning outcomes in ecology sub materials with a correlation coefficient of 0,496 meaning it had a moderate closeness of the relationship.
\end{abstract}

Keywords: ecology, generic science skills, learning outcomes

\begin{abstract}
Abstrak: Korelasi Antara Kemampuan Generik Sains Dengan Hasil Belajar Pada Konsep Ekologi. Keterampilan generik sains merupakan hal yang penting dalam proses pembelajaran karena keterampilan generik sains salah satu faktor internal yang mempengaruhi pembelajaran. Penelitian ini bertujuan untuk mengetahui hubungan antara keterampilan generik sains dengan hasil belajar peserta didik pada konsep ekologi. Metode penelitian yang digunakan adalah studi korelasional. Pengambilan sampel dilakukan secara purposive sampling sebanyak 2 kelas yakni XI MIPA 3 dan XI MIPA 4 berjumlah 58 peserta didik. Teknik pengumpulan data berupa post-test sebanyak 25 butir soal berbentuk uraian pada konsep ekologi yang dilakukan sesudah pembelajaran. Teknik analisis data yang digunakan adalah uji regresi korelasi pearson product moment dengan $\alpha 0,05$. Hasil penelitian menunjukkan bahwa ada korelasi positif antara keterampilan generik sains dengan hasil belajar peserta didik pada sub konsep ekologi dengan koefisien korelasi sebesar 0,496 artinya memiliki keeratan hubungan yang sedang.
\end{abstract}

Kata kunci: ekologi, hasil belajar, keterampilan generik sains 


\section{PENDAHULUAN}

Belajar merupakan aktivitas yang dilakukan peserta didik dan bersifat kompleks sehingga menghasilkan suatu perubahan sikap dan penambahan pengetahuan. Belajar dapat dilakukan dengan berbagai metode dan media, namun tingkat penyerapan hasil belajar bervariasi tergantung dari tingkat kemampuan peserta didik dalam menyerap informasi baik disampaikan oleh pendidik maupun dari pengalaman nyata yang mereka peroleh. Pembelajaran biologi tidak hanya menekankan aspek hafalan-hafalan, melainkan juga menyiapkan peserta didik yang cakap berpikir dalam pemecahan masalah (skills) untuk mendukung kehidupannya kini maupun yang akan dating. Maka dari itu, diharapkan dengan pembelajaran biologi dapat memberikan pengalaman secara langsung sehingga dapat meningkatkan minat peserta didik dalam mengembangkan pengetahuan dan keterampilan. Keterampilan yang selalu diasah akan menimbulkan bakat, bahkan dengan adanya keterampilan dari bidang apapun dapat membantu seseorang dalam berkarir. "Salah satu keterampilan yang berguna untuk melanjutkan pendidikan dan kesuksesan karir adalah keterampilan generik sains" (Tawil dan Liliasari, 2014).

Keterampilan generik sains perannya amat penting dalam membangun kepribadian dan pola berpikir tingkat tinggi. Keterampilan generik tidak diperoleh secara tiba-tiba melainkan keterampilan itu harus dilatih agar terus meningkat. "Tujuan keterampilan generik sains adalah agar pengetahuan dan keterampilan yang diperoleh proses belajar mengajar dapat diaplikasikan dalam kehidupan nyata" (Kusdiwelirawan, 2015). Sejalan dengan hal tersebut maka keterampilan generik sains sangat penting diterapkan untuk meningkatkan kemampuan pemahaman konsep dan membangun konsep baru sehingga dapat meningkatkan hasil belajar.

Berdasarkan hasil wawancara dengan guru biologi kelas XI SMA Negeri 10 Tasikmalaya tahun ajaran 2020/2021 diperoleh informasi bahwa terdapat perbedaan hasil belajar peserta didik antara satu dengan lainnya. Hal tersebut dikarenakan rendahnya pemahaman peserta didik dalam menangkap materi pembelajaran biologi, sehingga hasil belajar belum maksimal. Maka dari itu perlu adanya pembelajaran dengan menggunakan keterampilan skil agar peserta didik dituntut mampu belajar mandiri dengan melihat keterampilannya, sehingga diharapkan peserta didik mendapatkan hasil belajar yang lebih baik dari sebelumnya. Oleh karena itu, keterampilan generik sains perlu diterapkan untuk melatih peserta didik mengembangkan kemampuan sainsnya melalui keterampilan generik dan jika peserta didik dibiasakan untuk menggunakan keterampilan generik sains dapat memicu peningkatan pemahaman konsep sains sehingga dapat menentukan keberhasilan belajar. Berdasarkan hasil penelitian terdahulu yang pernah dilakukan oleh Agustinaningsih, W., et all. (2014) terkait pengembangan keterampilan generik sains mengayatakan bahwa peserta didik dapat berubah dari pembelajaran pasif menjadi pembelajaran aktif dengan penerapan diskusi informasi sehingga peserta didik dapat berbagi ide dan pemikiran dalam proses pembelajaran.

Oleh karena itu penulis melakukan penelitian ini dengan tujuan untuk mengetahui korelasi antara keterampilan generik sains dengan hasil belajar, dengan melibatkan keterampilan generik sains dan hasil belajar pada peserta didik kelas XI MIPA pada konsep ekologi di SMA Negeri 10 Tasikmalaya pada semester genap tahun pelajaran 2020/2021.

\section{METODE}


Populasi dalam penelitian ini adalah seluruh kelas XI MIPA SMA Negeri 10 Tasikmalaya tahun ajaran 2020/2021, sebanyak 4 kelas. Sampel dalam penelitian ini diambil dengan menggunakan teknik Purposive sampling yaitu kelas XI MIPA 3 dan XI MIPA 4.

Instrumen penelitian yang digunakan dalam penelitian ini adalah tes tulis keterampilan generik sains sebanyak 21 butir soal berbentuk uraian yang disusun atas 3 indikator keterampilan generik sains yaitu bahasa simbolik, hukum sebab akibat, dan membangun konsep.

Desain penelitian yang digunakan dalam penelitian ini adalah desain korelasional eksplanatori adalah desain korelasional dimana peneliti tertarik dalam dua variabel (atau lebih) bervariasi, yaitu dimana perubahan dalam satu variabel merefleksi perubahan variabel lain (Creswell,2008). Adapun model desain penelitian yang digunakan adalah paradigma sederhana dengan satu variabel independen dan dependen. Hal ini dapat digambarkan sebagai berikut:

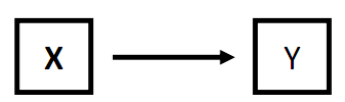
Data analisis
Ket : $\quad X=$ Keterampilan Generik menggunakan
uji hipotesis. Uji Sains $\mathrm{Y}=$ Hasil belajar
dengan prasyarat analisis dan normalitas dianalisis dengan uji Kolmogorov-smirnov dan uji linearitas regresi di analisis dengan di uji t. Hipotesis dianalisis dengan menggunakan uji pearson. Keseluruhan analisis data dilakukan dengan menggunakan spss for windows versi 23.

\section{HASIL DAN PEMBAHASAN}

Berdasarkan hasil penelitian yang diperoleh melalui posttest menggunakan instrument hasil belajar dan angket minat belajar peserta didik pada materi keanekaragaman hayati kelas $\mathrm{X}$ yang terdiri dari 36 peserta didik. Berikut ini data statistik hasil belajar dengan minat belajar dapat dilihat pada table 1 dan 2 .

Tabel 1. Statistik Hasil Belajar

\begin{tabular}{|c|c|c|c|c|c|c|c|c|}
\hline & $\mathrm{N}$ & Range & Minimum & Maximum & \multicolumn{2}{|c|}{ Mean } & Std. Deviation & Variance \\
\cline { 2 - 9 } & Statistic & Statistic & Statistic & Statistic & Statistic & Std. Error & Statistic & Statistic \\
\hline Hasil Belajar & 58 & 5.00 & 18.00 & 23.00 & 20.3103 & .19861 & 1.51260 & 2.288 \\
Valid N (listwise) & 58 & & & & & & & \\
\hline
\end{tabular}

Sumber : Hasil Pengolahan Data statistic menggunakan SPSS 23 for windows

Tabel di atas menjelaskan data statistika hasil belajar peserta didik kelas XI IPA SMA Negeri 10 Tasikmalaya. Berdasarkan tabel tersebut diperoleh sampel yang digunakan dalam penelitian sebanyak 58 peserta didik, dengan rentang sebesar 5, skor terendah yaitu 18 dan skor tertinggi 23 , dengan rata-rata 20,31, standar deviasi 1,512, dan varian 2,288 . 
Tabel 2. Statistik Keterampilan Generik Sains Descriptive Statistics

\begin{tabular}{|l|r|r|r|r|r|r|r|r|}
\hline & \multicolumn{1}{|c|}{$\mathrm{N}$} & \multicolumn{1}{|c|}{ Range } & Minimum & Maximum & \multicolumn{2}{|c|}{ Mean } & Std. Deviation & Variance \\
\cline { 2 - 9 } & Statistic & Statistic & Statistic & Statistic & Statistic & Std. Error & Statistic & Statistic \\
\hline KGS & 58 & 10.00 & 17.00 & 27.00 & 22.6724 & .36181 & 2.75546 & 7.593 \\
Valid N (listwise) & 58 & & & & & & & \\
\hline
\end{tabular}

Sumber : Hasil pengolahan data menggunakan SPSS versi 23 for windows

Tabel di atas menyajikan data menggunakan SPSS versi 23 for windows XI MIPA 3 dan MIPA 4, dengan sampel yang digunakan sebanyak 58 peserta didik. Dengan rentang 10. Dan memiliki skor minimum 17 dan skor maksimum 27, dengan rata-rata 22,67, standar deviasi 2,75, varian 7,5.

Selanjutnya untuk uji normalitas menggunakan uji Kolmogorov-Smirnov untuk mengetahui data berdistribusi normal atau tidak, data yang berdistribusi normal apabila nilai signifikansi lebih dari 0,05. Adapun hasil uji normalitas keterampilan generik sains dan hasil belajar peserta didik dapat dilihat pada tebel 3 .

Tabel 3. Hasil Uji Data Normalitas dengan Kolmogorov Smirnov

\begin{tabular}{ccccc} 
Variabel & N & Asymp.sig & Signifikasi & Kesimpulan Analisis \\
(2-tailed $)$ & $(\alpha)$ & 0,05 & $\begin{array}{c}\text { Data berasal dari populasi yang } \\
\text { berdistribusi normal }\end{array}$ \\
\hline KGS & 58 & 0,200 & 0,05 & $\begin{array}{c}\text { Data berasal dari populasi yang } \\
\text { berdistribusi normal }\end{array}$
\end{tabular}

Sumber : Hasil Analisis menggunakan SPSS for windows versi 23

Berdasarkan tabel 3 dapat disimpulkan bahwa data yang berasal dari 58 peserta didik, didapatkan data dengan nilai Asymp.sig keterampilan generik sains sebesar 0,200 dan hasil belajar sebesar 0,052. Karena nilai Asymp.sig lebih besar dari 0,05 sehingga dapat disimpulkan bahawa data keterampilan generik sains dan hasil belajar peserta didik berasal dari data yang berdistribusi normal.

Uji prasyarat selanjutnya yang dilakukan yaitu uji linearitas. Uji ini digunakan untuk mengetahui distribusi data penelitian memiliki hubungan yang linier atau tidak. Adapun hasil pengujian linearitas keterampilan generik sains dengan hasil belajar peserta didik dengan menggunakan aplikasi SPSS versi 23 for windows dengan taraf signifikansi 5\%. Adapun hasil uji linearitas minat belajar dengan hasil belajar peserta didik dapat dilihat pada tabel 4.

Tabel 4. Hasil Uji Data Linearitas

\begin{tabular}{|c|c|c|c|c|c|c|c|}
\hline \multicolumn{8}{|c|}{ ANOVA TABLE } \\
\hline & & & $\begin{array}{c}\text { Sum of } \\
\text { Squares }\end{array}$ & Df & $\begin{array}{l}\text { Mean } \\
\text { Square }\end{array}$ & $\mathrm{F}$ & Sig. \\
\hline Hasil Belajar * & Between & (Combined) & 41.981 & 8 & 5.248 & 2.908 & .010 \\
\hline
\end{tabular}




\begin{tabular}{|c|c|c|c|c|c|c|c|}
\hline KGS & Groups & $\begin{array}{l}\text { Linearity } \\
\text { Deviation from } \\
\text { Linearity } \\
\end{array}$ & $\begin{array}{r}32.117 \\
9.864\end{array}$ & $\begin{array}{l}1 \\
7\end{array} \mid$ & $\begin{array}{r}32.117 \\
1.409\end{array}$ & $\begin{array}{r}17.796 \\
.781\end{array}$ & $\begin{array}{l}.000 \\
.606\end{array}$ \\
\hline & Within Groups & & 88.433 & 49 & 1.805 & & \\
\hline & Total & & 130.414 & 57 & & & \\
\hline
\end{tabular}

Sumber : Hasil Analisis menggunakan SPSS for windows versi 23

Berdasarkan hasil analisis uji linearitas menggunakan uji linear di dapatkan hasil sig 0,606. Karena nilai signifikasi lebih dari 0,05 maka dapat disimpulkan bahwa data pada peserta didik memiliki hubungan yang linier.

Berikut diagram scatterplot dari keterampilan generik sains terhadap hasil belajar peserta didik dapat dilihat pada gambar 1.

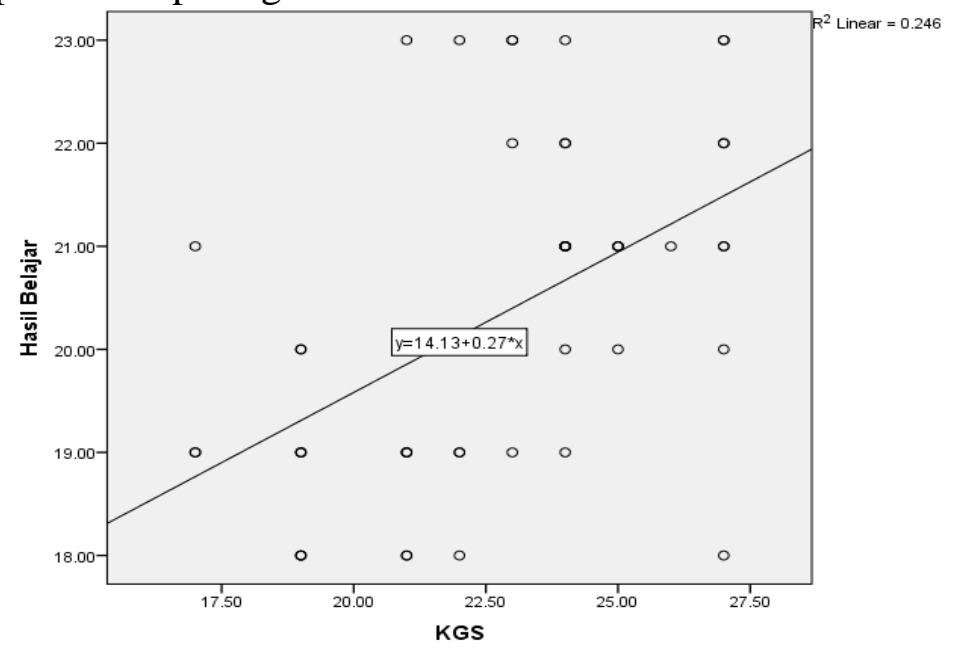

Gambar 1. Grafik Scatterplot Keterampilan Generik Sains dengan Hasil Belajar

Berdasarkan gambar 1 terlihat terlihat pola garis linearitas, antara keterampilan generik sains dengan hasil belajar. Adapun persamaan regresi yang diperoleh adalah Ý $=14,134+0,27 \mathrm{x}$. Persamaan regresi menunjukan nilai a adalah 14,134 dan nilai $\mathrm{b}$ adalah 0,27

Untuk mengetahui ada atau tidaknya hubungan keterampilan generik sains dengan hasil belajar peserta didik, maka dilakukan uji hipotesis korelasi pearson menggunakan SPSS versi 23 for windows dengan taraf signifikansi $5 \%$.

Berdasarkan hasil uji hipotesis korelasi pearson, nilai signifikansi yang diperoleh sebesar 0,000 yang berarti ada hubungan anatara keterampilan generic sains dengan hasil belajar. Nilai koefisien korelasi (R) sebesar 0,496 dan nilai koefisien determinasi $\left(\mathrm{R}^{2}\right)$ sebesar 0,246. Sehingga dapat disimpulkan bahwa keterampilan generik sains memiliki kekuatan hubungan sebesar 0,496 serta variabel hasil belajar memberikan kontribusi sebesar $24,6 \%$.

Adapun berdasarkan perolehan skor rata-rata perindikator keterampilan generic sains peserta didik, dapat dilihat pada diagram berikut ini (gambar 2). 


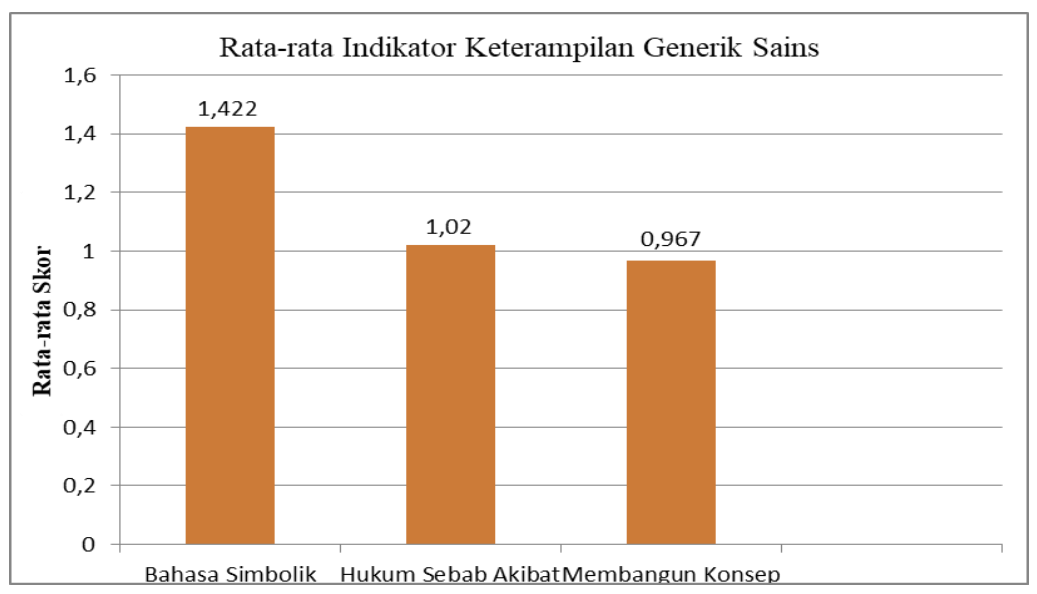

Gambar 2. Hasil Skor Rata-rata Aspek Keterampilan Generik Sains

Berdasarkan diagram (gambar 2) menunjukkan bahwa skor post-test tertinggi terdapat pada indikator bahasa simbolik dengan rata-rata sebesar 2,23 dan skor terendah pada indikator membangun konsep dengan rata-rata sebesar 0,967. Perbedaan skor tersebut terjadi karena dalam indikator bahasa simbolik terdapat sub indikator memahami simbol, lambang dan istilah. Mendapat nilai rata-rata yang tinggi karena soal yang disajikan hanya sedikit yakni 2 buah soal bahasa simbolik, dan menyangkut simbol-simbol yang telah dipelajari di beberapa mata pelajaran. Hal tersebut dikarenakan pengalaman belajar peserta didik mampu memahami materi pembelajaran dan dapat menghafal simbol-simbol dalam konsep ekologi.

Hal ini sejalan dengan penelitian Sri Agustin, dkk (2013) hasil tes menunjukkan $76 \%$ mencapai kriteria ketuntasan. Dan hasil observasi menunjukkan bahwa komponen keterampilan generik sains yang sering muncul yaitu bahasa simbolik sebesar 58\%, permodelan matematik senilai $58 \%$ sedangkan keterampilan yang paling rendah presentase kemunculannya adalah keterampilan kesadaran akan skala besaran sebesar $53 \%$.

Sedangkan indikator membangun konsep lebih rendah daripada indikator yang lainnya. Hal tersebut menunjukkan bahwa peserta didik kurang optimal dalam memahami dan membangun konsep-konsep baru dalam pembelajaran. Hal tersebut disebabkan materi ekologi dianggap sulit untuk dihafalkan dan dipahami. Hal ini sejalan dengan penelitian

Misbahul Jannah (2019) menyatakan dalam penelitian KGS nya berada pada kategori kurang, dan hanya meningkat secara signifikan pada dua aspek KGS yaitu bahasa simbolik dan aspek berfikir dalam kerangka logika taat azas. Sedangkan aspek membangun konsep berada pada kategori kurang. Hal ini menunjukkan perlu adanya peningkatan kemampuan dalam membangun konsep. Jika peserta didik mempunya kemampuan yang sangat baik dalam membangun konsep akan dapat membuat kesimpulan yang baik dalam bentuk gambar, grafik, dan pernyataan-pernyataan selama pembelajaran berlangsung.

Adapun data hasil belajar dalam penelitian ini diperoleh dari pengumpulan data skor hasil belajar pada konsep ekologi yang diambil dari nilai ulangan harian berupa data base dari guru mata pelajaran biologi kelas X MIPA 4 dan MIPA 5 SMA Negeri 10 Tasikmalaya. Untuk mengetahui pencapaian hasil belajar peserta didi pada konsep ekologi dapat dilihat pada gambar di bawah ini. 


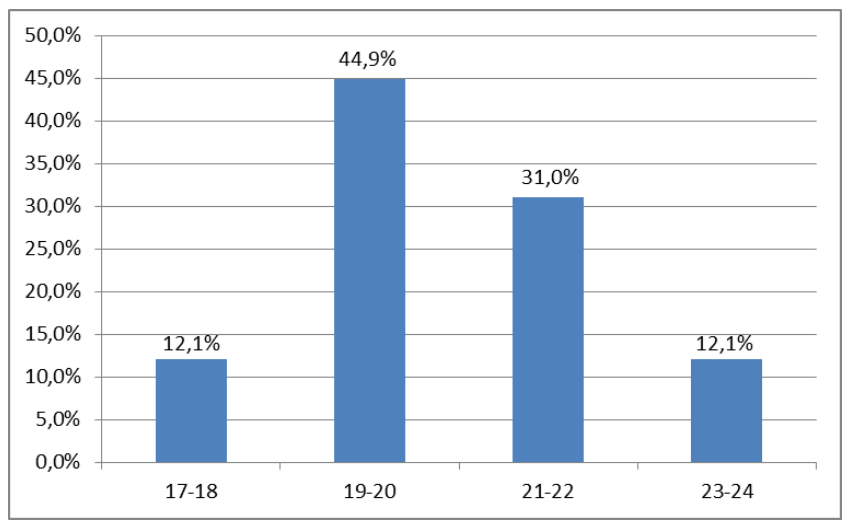

Gambar 3. Presentase Kategori Hasil Belajar

Dari gambar di atas dapat dijelaskan bahwa hasil analisis deskriptif hasil belajar pada peserta didik dari 58 orang peserta didik menggambarkan bahwa batas kelas terendah memiliki presentase terendah $12,1 \%$ sedangkan presentase tertinggi ada pada batas kelas tengah yaitu 19-20 dengan presentase 44,9\%. Sedangkan untuk batas kelas tertinggi memiliki presentasi $12,1 \%$ sisa nya berada pada batas kelas tengah antara 21 22 dengan presentase $31,0 \%$. Jadi dapat disimpulkan bahwa hasil penelitian yang diperoleh menunjukkan skor hasil belajar peserta didik pada konsep ekologi masih banyak yang dibawah batas kelas rendah sehingga hasil belajar peserta didik masih perlu banyak untuk ditingkatkan.

Berdasarkan hasil uji hipotesis dengan menggunakan uji korelasi pearson product moment dengan menggunakan SPSS 23 for windows, diperoleh nilai signifikansi sebesar 0,000 dengan menggunakan taraf signifikansi $<0,05$, menunjukkan bahwa ada hubungan antara keterampilan generik sains dengan hasil belajar peserta didik pada sub konsep ekologi secara signifikan. Korelasi antara keterampilan generik sains dengan hasil belajar pada sub konsep ekologi sebesar 0,496 yang menunjukkan derajat korelasi termasuk dalam kategori sedang. Adapun persamaan regresi yang diperoleh adalah $\hat{Y}=$ $\hat{Y}=14,134+0,272 x$.

Berdasarkan uji hipotesis yang telah diuraikan sebelumnya, maka dapat disimpulkan bahwa ada hubungan yang positif antara keterampilan generik sains dengan hasil belajar, dimana keterampilan generik sains dapat menjadi faktor keberhasilan peserta didik dalam mencapai hasil belajar yang optimal. Peserta didik yang memiliki keterampilan generik sains terhadap mata pelajaran biologi khususnya pada sub konsep ekologi akan mengeluarkan ide-ide serta keterampilan dasar nya dalam pembelajaran biologi khsusunya sub konsep ekologi. Sehingga memungkinkan peserta didik untuk belajar lebih giat, mengasah keterampilan dalam membangun konsep-konsep sains, sehingga akan diperoleh hasil belajar yang maksimal.

Hal tersebut sejalan dengan yang pernah dilakukan Nabila Nur Lathifa, dkk. (2019), penelitian tersebut menyimpulkan pada uji korelasi terdapat hubungan yang positif dan signifikan antara pelaksanaan praktikum dengan hasil belajar peserta didik. Selanjutnya terdapat hubungan yang postif dan signifikan 36 antara keterampilan generik sains peserta didik dengan hasil belajar peserta didik, yang memiliki nilai koefisien pada uji korelasi yaitu 0,791 mengindikasikan hubungan yang kuat antara keterampilan generik sains dengan hasil belajar peserta didik. 


\section{SIMPULAN}

Berdasarkan hasil penelitian dan pembahasan yang telah dilakukan dapat di tarik kesimpulan bahwa penelitian ini menunjukan adanya hubungan antara keterampilan generik sains dengan hasil belajar peserta didik pada sub konsep ekologi di kelas XI IPA di SMA Negeri 10 Tasikmalaya. Koefisien korelasi sebesar $(r)=0,496$ yang berarti hubungan antara variabel termasuk dalam kategori sedang. Hal ini menandakan semakin besar keterampilan generik sains makan hasil belajar akan semakin tinggi. Keterampilan generik sains kelas XI MIPA 3 dan MIPA 4 di SMA Negeri 10 Tasikmalaya berada pada kategori sedang.

Keterampilan generik sains saling berhubungan dengan hasil belajar dan mampu meningkatkan hasil belajar peserta didik; untuk penelitian selanjutnya diharapkan keterampilan generik sains mampu meningkatkan kualitas pendidikan; Penelitian ini diperlukan adanya kajian lebih mendalam mengenai minat belajar dan faktor-faktor lainnya yang mempengaruhi hasil belajar terutama dalam pembelajaran biologi.

\section{DAFTAR RUJUKAN}

Abidin, Yunus. (2014). Desain Sistem Pembelajaran dalam Konteks Kurikulum 2013. Bandung: PT Refika aditama.

Al-Tabany, Trianto Ibnu Badar. (2014). Mendesain Model Pembelajaran Inovatif, Progresif dan Kontekstual. Jakarta: Prenadamedia Group.

Arikunto, Suharsimi. (2006). Dasar-dasar Evaluasi Pendidikan. Jakarta: Bumi Aksara.

Arikunto, Suharsimi. (2013). Prosedur Penelitian: Suatu Pendekatan Praktik. Jakarta: Rineka Cipta.

Budianti, Herni. (2012). Biologi Jilid I untuk SMA/MA Kelas X. Jakarta: CV Gema Ilmu.

Campbell, Neil. A dan Jane B. Reece. (2010). Biologi Edisi 8 Jilid 3 Neil A. Campell \& Jane B. Reece. Jakarta: Erlanga.

Dewi, Pradita Hangesti. et.al.,. (2019) "Peningkatan Aktifitas dan Hasil Belajar melalui Model Problem Based Learning (PBL) pada Materi Pencemaran Lingkungan Siswa Kelas X SMA Negeri 1 Jatisrono". e-Journal Program Studi Pendidikan Biologi Universitas Veteran Bangun Nusantara. Sukoharjo, Indonesia, 1(1), 53-62.

Doi : http://journal.univetbantara.ac.id/index.php/JBL/article/view/251

Hosnan. (2014). Pendekatan Saintifik dalam Pembelajaran Abad 21. Bogor: Ghalia Indonesia.

Istianah, Rachmawati. et.al.,. (2015). "Pengembangan Perangkat Pembelajaran Berbasis Masalah (Problem Based Learning) Untuk Meningkatkan Keterampilan Generik Sains Siswa SMA". e-Journal Program Studi Pendidikan IPA Program Pascasarjana Universitas Negeri Semarang. Semarang, Indonesia, 4(1), 1-9.

Doi : https://journal.unnes.ac.id/sju/index.php/jise/article/view/6891

Joyce burce, et.al. (2009). Model Of Teaching Model-model Pengajaran. Yogyakarta: Pustaka Pelajar.

Kosasih, E. (2014). Strategi belajar dan Pembelajaran Implementasi kurikulum 2013. Bandung: Yrama Widya.

Kusdiwelirawan, A., T. I. Hartini, \& A. R. Najihah (2015). Perbandingan Peningkatan Keterampilan Generik Sains antara Model Inquiry Based Learning dengan Model Problem Based Learning. Jurnal Fisika dan Pendidikan Fisika, 1(2), 19-22.

Doi : http://www.jurnalomega.org/index.php/omega/article/download/36/42 
Latipun, (2004). Psikologi Eksperimen. Malang: UMM Press.

Maryati, Sri. (2012). Biologi Untuk SMA/MA Kelas X. Jakarta: Erlangga

Meltzer, David E. (2012). "The Relationship Between Matematics Preparation and Conceptial Learning Gains in Physicn: A possible" hidden variable" indiagnostic pretest score" American Journal of Physics, 70(12), 1250-1268. Doi : http://www.physicseducation.net/docs/AJP-Dec-2002-Vol.70-1259-1268.pdf

Rahman, Taufik, et.al.,. (2006). "Profit Kemampuan Generik Perencanaan Percobaan Calon Guru Hasil Pembahasan Berbasis Kemampuan Generik Pada Praktikum Fisiologi Tumbuhan". Educare. 4:1. Bandung, 4(1),

Rusman. (2014). Model-model Pembelajaran Mengembangkan Profesionalisme Guru. Jakarta: PT Raja Grafindo Persada.

Rusmono. (2014). Strategi Pembelajaran dengan Problem Based Learning Itu Perlu. Bogor: Ghalia Indonesia.

Shoimin, Aris. (2014). 68 Model Pembelajaran Inovatif dalam Kurikulum 2013. Yogyakarta: Arruz Media.

Slameto. (2013). Belajar dan Faktor-faktor yang mempengaruhinya. Jakarta: PT. Rineka Cipta.

Slameto. (2015). Belajar dan Faktor-faktor yang mempengaruhinya. Cetakan Keenam: Jakarta: PT Rineka Cipta.

Sudarmin. (2012). Keteampilan Generik Sains dan Penerapannya dalam Pembelajaran Kimia Organik. Semarang: UNNES Press.

Sugiyono. (2015). Metode Penelitian Pendidikan (Pendekatan Kuantitatif, Kualitatif dan $R \& D)$. Bandung: CV Alfabeta.

Sugiyono. (2017). Metode Penelitian Kuantitatif, Kualitatif dan R\&D. Bandung: CV Alfabeta.

Sukardi. (2007). Metodologi Penelitian Pendidikan. Yogyakarta: Bumi Aksara.

Sunyono. (2009). Pembelajaran IPA dengan Keterampilan Generik Sains. (online) (http//Unila.ac.id, diakses 10 September 2019)

Susanti, R. (2013). Pengaruh Penerapan Pembelajaran Berbasis Masalah pada Praktikum Fotosintesis dan Respirasi untuk Meningkatkan Kemampuan Generik Sains Mahasiswa Pendidikan Biologi FKIP Unsri.

Tawil, M. Liliasari. (2014). Keterampilan-keterampilan Sains dalam Implementasinya dalam Pembelajaran IPA.

Yamin, Martinis. (2008). Desain Pembelajaran Berbasis Tingkat Satuan Pendidikan. Jakarta: Gaung Persada Press.

Yani, Riana. (2012). Ekosistem Sebagai Lingkungan Hidup Manusia. Jakarta: PT Remaja Rosdakarya. 